\title{
IMPROVED CHEMICAL TREATMENT OF SUŠICA SURFACE WATER, ZLATIBOR AREA, AND SLUDGE APPLICATION
}

\author{
Mirjana R. Cvijovića ${ }^{\text {, Milorad R. Murić }}{ }^{b}$, Vladica V. Čudićc \\ a University of Belgrade, Faculty of Medicine, Institute for Microbiology \\ and Immunology, Belgrade, Republic of Serbia, \\ e-mail: miracvijovic970@gmail.com, corresponding author, \\ ORCID iD: (iohttps://orcid.org/0000-0002-1965-8852 \\ ${ }^{\mathrm{b}}$ Academy of Vocational Studies of Western Serbia, \\ Užice, Republic of Serbia, \\ e-mail: muricmilorad@outlook.com, \\ ORCID iD: Dhttps://orcid.org/0000-0003-0098-5180 \\ ${ }^{c}$ PWW LLC, Office in Belgrade, Belgrade, Republic of Serbia, \\ e-mail: vladica.cudic@gmail.com, \\ ORCID iD: Dhttps://orcid.org/0000-0002-4756-7106
}

DOI:10.5937/vojtehg68-26177; https://doi.org/10.5937/vojtehg68-26177

FIELD: Chemical Technology

ARTICLE TYPE: Original Scientific Paper

ARTICLE LANGUAGE: English

\begin{abstract}
:
Introduction/purpose: Sušica source surface water varies in natural organic and inorganic impurities, biological species and micro-organisms. This water is used instead of Vrutci lake water that has been stronglly affected by eutrophication. These waters need removal of pollutants with coagulants and polyelectrolyte. The aim of research was to improve the surface water treatment (coagulation and flocculation), to reduce sludge amount and to evaluate its quality, treatment and application.

Methods: The physical-chemical methods are developed for determining the quality parameters of water, sludge and compost. These parameters are: turbidity, $\mathrm{KMnO}_{4}$ consumption, metals, total organic carbon, total nitrogen, and chlorophyll.

Results: Surface water quality has a strong impact on sludge. The concentrations of metals in the sludge were: $72200 \mathrm{mgkg}-1 \mathrm{Al}, 8550$ mgkg-1 Fe, and $106 \mathrm{mgkg}-1 \mathrm{Zn}$. The metals over the maximum limit were: Ni 169 mgkg-1, Cr 69.5 mgkg-1, Pb 5.7 mgkg-1, and they have to be reduced by zeolite. The „nutrients” concentrations were: $697 \mathrm{mgkg}-1 \mathrm{P}$, 297 mgkg-1 K, 9.6 mgkg-1 total N, and 274 mgkg-1 of dissolved organic carbon. Escherichia coli and Salamonella are important for converting sludge to compost.
\end{abstract}

ACKNOWLEDGEMENTS: The researchers would like to thank the colleagues from the Public Health Institute Užice for peer support. 


\begin{abstract}
Conclusions: After maturation, compost can be used for Coriandrum sativum cultivation. In further work, this strategy should be applied to the water and sludge from Vrutci lake.
\end{abstract}

Key words: surface water, water flow, coagulation, flocculation, sludge, compost.

\title{
Introduction
}

Water is a public, renewable and easily accessible resource. Unfortunately, it is often not treated as a significant environmental, economic and social factor. United Nations experts estimate that in this year, 2020, two-thirds of people on Earth live in water-scarce areas. A large number of water bodies such as rivers, lakes, seas, and oceans are being affected by the eutrophication process. Due to geological aging and leaching from the surrounding catchment areas, the nutrient levels in water gradually increase and water bodies move from oligotrophic to eutotrophic. In this way, problems in Vrutci lake began. There was a significant decrease in dissolved oxygen concentration (DO) and increase in chemical oxygen demand (COD). Cyanobacteria bloom occurred, caused by eutrophication and global warming of these aquatic ecosystems. Similar results (Christophoridis et al, 2018.) were presented for algal blooms and the occurrence of cyanotoxins in 14 lakes in Greece, firstly determined by Elisa tests for several types of cyanotoxins (microcystins). Then the authors used microscopic identification with taxonomic keys, as well as liquid tandem mass spectrometry with electrospray ionization and chromatographic separation in multiple reaction monitoring mode (MRM) for the identification of all species and for their quantification. Cyanobacteria are photosynthetic prokaryotic organisms which reproduce rapidly, forming cyanobacterial "blooming" water. A prerequisite for the occurrence of cyanobacteria and their dominance is a decrease in the ratio of total nitrogen to total phosphorus (TN:TP) to a value of 10 or less. Phytoplankton has a great influence on the surface water quality, no matter which area - the Mediterranean area, the Marathonas Reservoir or Bubanj and Sumarice lakes - is a subject of investigation. Phytoplankton depends on the availability of $\mathrm{CO}_{2}$, sun and nutrients. Phytoplankon degrading bacteria deplete water from oxygen and destroy living organisms. Phytoplankton is sizzling, but when it comes to water blooming, high concentrations of chlorophyll and other pigments appear as well as many species of algae (Katsiapi et al, 2011, pp .563-575), (Ranković et al, 2006, pp.107-114). The increase in phosphorus, an indicator of the occurrence of water blooming and the 
development of phytoplankton, Planktothrix rubescens, from the Cyanobacteria group, was recorded in Vrutci Lake. Excessive contamination of the Vrutci lake water appeared as well as the development of pathogenic bacteria. As a result, the water treatment plant was not able to purify the modified water. Therefore, the Vrutci reservoir was disconnected from the water supply system and replaced with the surface raw water from the Sušica river source, Fig 1. The Sušica river is classified as type 6 of water and II-III surface water class, in accordance with the Regulations on the parameters of the ecological and chemical status of surface waters and the parameters of the chemical and quantitative status of groundwaters (Official Gazette of the Republic of Serbia, $N^{\circ} 74 / 2011$ ).

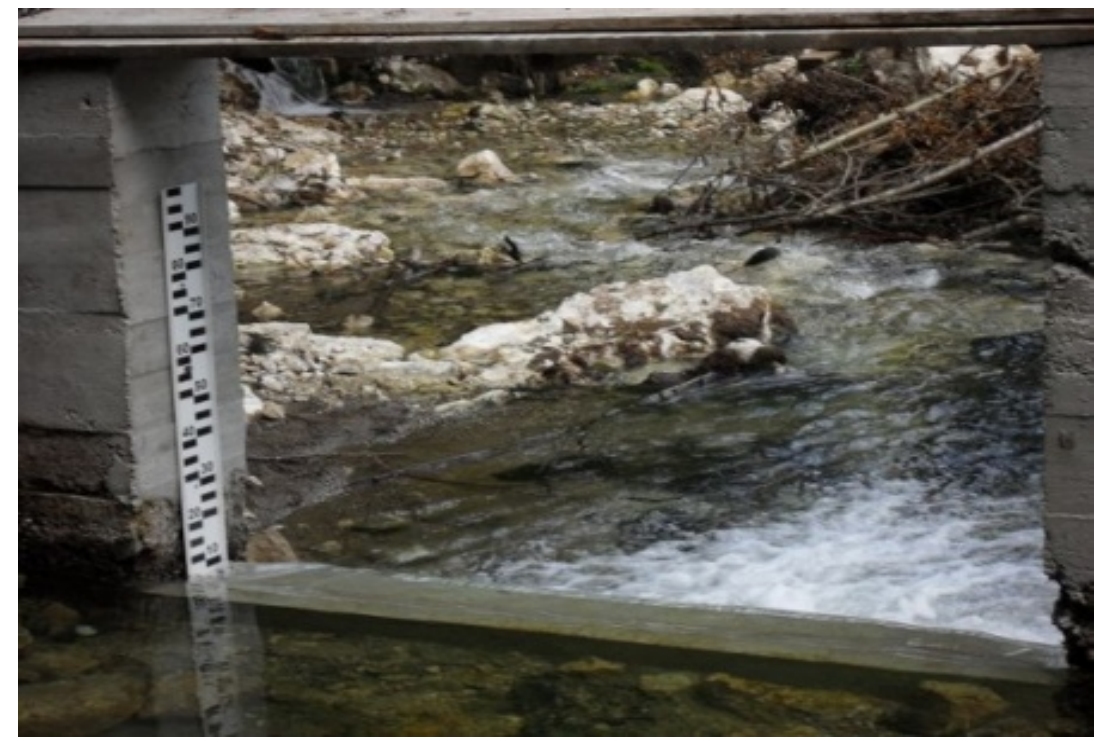

Figure 1 - Sušica river source

Puc. 1 - Исток реки Сушица

Слика 1 - Извориште реке Сушице

The water plant has been modernized: some lines have been reconstructed and some new lines have been built. In the process of treating surface raw water, besides the production of drinking water, waste water and sludge are generated as waste (including water with which filters have been washed and sludge after a sludge concentrator has been emptied). If drinking water is enriched with phytoplankton or other biological species as well as a lot of rainfall, it is necessary to use 
more doses of chemicals such as Al-inorganic coagulants and organic flocculant, polyelectrolyte.

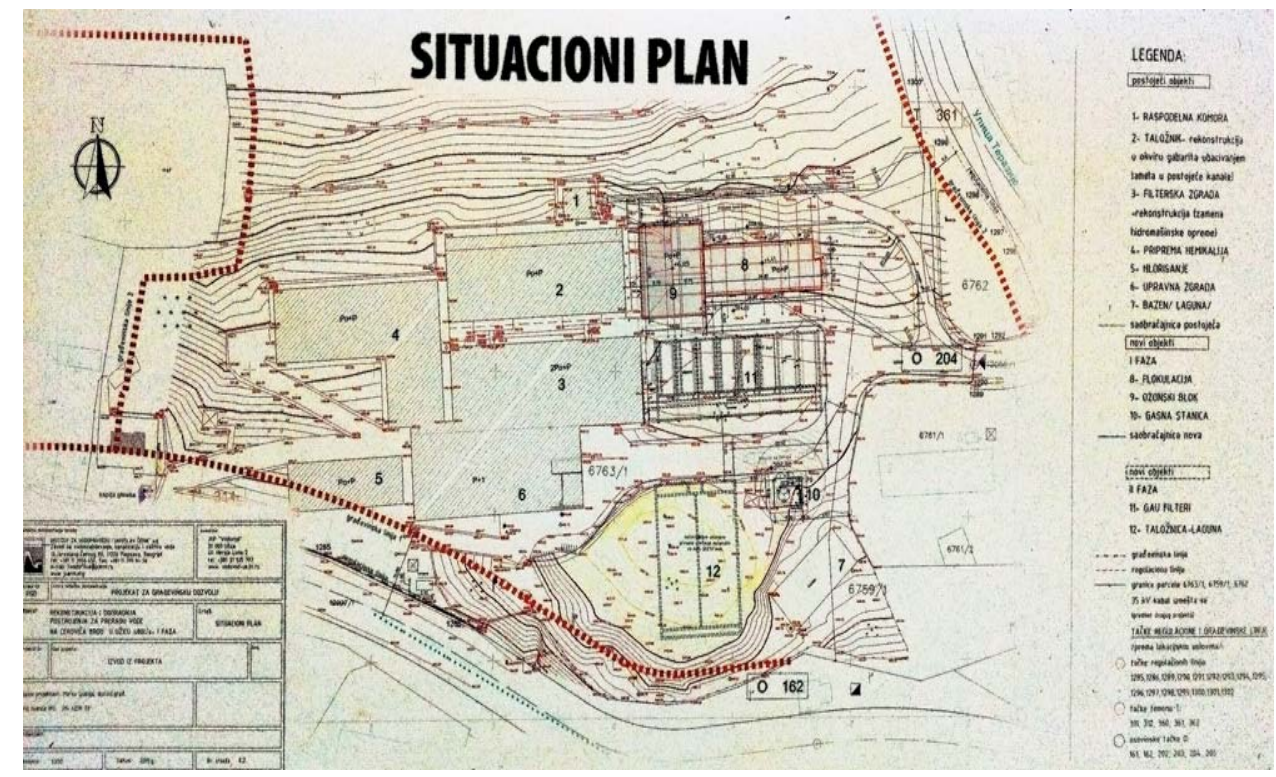

Figure 2 - Situation plan of the water supply plant

Puc. 2 - Ситуационный план для водоочистного сооружения

Слика 2 - Ситуациони план постројења за прераду воде

Figure 2 shows the situation plan (done by The Jaroslav Černi Institute for the Development of Water Resources, Belgrade, Serbia) and the reconstruction phases of the raw water treatment plant that operated in the "classical" way during 2017. At the very beginning of 2018, the first phase of reconstruction was released. This phase included the reconstruction of the part for the preparation of coagulants and laminar precipitators, as well as the construction of new objects: flocculation, ozone block and gas stations.

The sludge formation is mostly influenced by the quality of surface water, treatment processes (coagulation and flocculation), and the amount of water influx into the water treatment plant. The interdependence of raw water quantity in function of doses of chemicals was analyzed in the time before the technological reconstruction in 2017, with a classic water treatment and after the water plant reconstruction, with an improved treatment of the Sušica surface water in 2018. The technical improvement in the flocculation section included three speed mixing machines with reducer motors of different power that contribute to 
more efficient flocculation. The „high quality“ flocculas are deposited on the laminar sedimentation tanks and after sapling sludge is obtained, undergoing dehydration by automatic dosing of polyelectrolytes. The reconstruction of the water plant also respected environmental principles and reduced the amount of generated sludge. $Q$. Malik dealt with similar issues (Malik, 2018.) He presented the method for reducing the generated sludge amount during the coagulation/flocculation process and for minimizing costs of deposition of by-products from the water treatment process. When surface water is treated with Al-sulphate, the $\mathrm{pH}$ of the treated water increases as a consequence of the high degree of basicity of this coagulant. Compared to other coagulants, Al-sulphate has lower efficiency. The optimal technological conditions for removing high turbidity are chosen. For example, for 250 NTU turbidity is removed with Al-sulphate doses of $0.25 \mathrm{~g} / \mathrm{l}, \mathrm{pH} 6$, with the deposition time of 30 minutes. The similar concept of a physico-chemical treatment (coagulation-flocculation) is applicable (Aguilar et al, 2005, pp.47-56) to waste water, using anionic polyacrylamide as an additional chemical for improving coagulation, optimizing the rate of flocculation. The optimum rate and the mixing time for a given degree of flocculation were consistent with the $\mathrm{pH}$ and the doses of the coagulant/flocculant. Chemical oxygen demand (COD), biochemical oxygen demand for 5 days $\left(\mathrm{BOD}_{5}\right)$, and total suspended particulate matter (TSS) were determined at the beginning and the end of each experiment to monitor the process of waste water clarification. Once the optimal conditions were established, other parameters were also measured to evaluate the coagulation/flocculation process: number and size of particles, sludge volume, nutrients (ammonia, nitrogen, total Kjeldahl nitrogen, orthophosphate, total phosphorus), and residual $\mathrm{Fe}^{3+}$ and $\mathrm{Al}^{3+}$ concentrations in purified water. Anionic polyacrylamide, added with $\mathrm{Fe}-$ sulphate or polyaluminum chloride, led to a significant increase in the deposition rate.

The process of treating raw surface water involves bringing colloidal particles to a certain range, during the process of clarification, i.e. coagulation/flocculation of water, thereby reducing the content of colloidal particles, performing discharging and aggregation. The next phases in removing pollutants are the removals of chemicals in excess and metabolic products through the processes of precipitation and filtration. The most commonly used coagulants are aluminum salts (sulphates or polychlorides) or iron salts. The chemistry of aluminum in surface water is described by complexation reactions during the coagulation/flocculation process: 

ions,

1. aluminum and inorganic ligands, sulphates, phosphates, hydroxyl

2. aluminum and organic ligands, aluminum-humic matter,

3. reactions of formation, monomers, polymers and precipitation formation:

- monomeric types of aluminum, $\mathrm{Al}^{3+}, \mathrm{Al}(\mathrm{OH})^{2+}, \mathrm{Al}(\mathrm{OH})_{2}{ }^{+}, \mathrm{Al}(\mathrm{OH})_{3}$, $\mathrm{Al}(\mathrm{OH})_{4}$

- polymer species, $\mathrm{Al}_{2}(\mathrm{OH})_{2}{ }^{4+}, \mathrm{Al}_{3}(\mathrm{OH})_{4}{ }^{5+}, \mathrm{Al}_{13} \mathrm{O}_{4}(\mathrm{OH})_{24}{ }^{7+}$

- precipitate $\mathrm{Al}(\mathrm{OH})_{3},(\mathrm{~s})$.

Cvijović and Djurdjevic in some papers (Cvijović et al, 2012, pp.1087-1097), (Cvijovic et al, 2012, pp.313-322), (Djurdjevic et al, 2005, pp.1615-1629) presented the results of studing monomeric species, polymeric species that form during complexation and hydrolysis of $\mathrm{Al}^{3+}$ ions and amino acids and antibiotics. By varying a degree of neutralization, metal-organic ligand ratio, temperature, $\mathrm{pH}$, the aging time of the Al-solution, mixing speed, different equilibrium species of aluminum and organic molecules are formed and with different yields. The amino acids and antibiotics ligands, in a similar way, bond to $\mathrm{Al}^{3+}$ ion as polyelectrolite, anionic polyacrilamide $\left(\mathrm{CH}_{2} \mathrm{CHC}=\mathrm{ONH}_{2}\right) \mathrm{n}$ across carbonyl oxygen and amino $\mathrm{N}$. The experimentally obtained species formed between L-histidine ( $\mathrm{HHis}$ ) ions and $\mathrm{Al}^{3+}$ ions in aqueous solution, detected by UV spectrophotometry at $298 \mathrm{~K}$ were: $\mathrm{Al}(\mathrm{HHis})^{3+}, \mathrm{Al}(\mathrm{His})^{2+}$, $\mathrm{Al}(\mathrm{HHis}) \mathrm{His}^{2+}$ or dimmer $\mathrm{Al}_{2}(\mathrm{OH}) \mathrm{His}_{2}{ }^{2+}$ with complex formation constants, indicators of complex stabilty: $\beta_{p, k, r}, \log \beta_{1,1,1}=11,90 \pm 0,04, \log \beta_{1,1,0}=$ $7,25 \pm 0,08, \log \beta_{1,2,1}=20,1 \pm 0,1$ and $\log \beta_{2,1,1}=5,92 \pm 0,12(p, k, r$ are the stoichiometric indices of metals, ligands, and protons). The formed species detected by ${ }^{27} \mathrm{Al}$ NMR spectroscopy were: $\mathrm{Al}(\mathrm{HHis})^{3+}$ and $\mathrm{Al}(\mathrm{HHis})(\mathrm{His})^{2+}$ or $\mathrm{Al}(\mathrm{OH})(\mathrm{HHis})_{2}{ }^{2+}$ and $\mathrm{Al}_{13}$ polymer. The polymer $\mathrm{Al}_{13} \mathrm{O}_{4}(\mathrm{OH})_{24}{ }^{7+}$, a major species formed in water solution of polyhydro aluminum chloride is more effective in water clarification (coagulation / flocculation), than Al- sulphate. Speciation occured similarly in fresh water with $\mathrm{Al}^{3+}$ or $\mathrm{Fe}^{3+}$ ions, most probably with similar complex formation constants. The species formed of $\mathrm{Al}^{3+}$ ion and antibiotics were investigated in water solution by tandem mass spectroscopy (Cvijovic et al, 2012, pp.313-322). The antibiotics ligands are often waste water contaminants.

This paper presents the results when the surface water from Vrutci lake was replaced with the surface water from the neighboring Sušica river source, i.e. the comparison of the amounts of chemicals used before and after the reconstruction of the water treatment plant; it also 
presents the amount of sludge in a conventional water treatment and improved technical-technollogical water treatments with reduced quantities of chemicals, which reduced sludge amount and resulted in higher efficiency and economical results.

The improvement also concerned the validation of physico-chemical methods based on instrumental techniques in the laboratory of the water treatment plant. The methods were applied for the analyses of surface water and generated sludge, assessing whether such sludge can be used for composting or growing medicinal plants or other species, in accordance with standard SRPS Z.T1.100:2017 (Institute for Standardization of Serbia, 2017), which prescribes clear requirements for the composting process, the selection of input materials and the minimal quality of the composted materials. The treatment of this sludge involves the removal of aluminum, because $\mathrm{Al}$ is considered to be a detrimental element. Sludge needs removal of toxic metals that are above the maximum permissible value. The treatment should be done by zeolite, as a real time removal of toxic metals (Kerkez, 2014) or by fitoremediation that is a long-standing way of treating metal-contaminated soil or sludge (Čudić et al, 2016, pp.229-239).

The environmental and economic effects of coagulation were also the focus of authors (Keeley et al, 2014, pp.2675-2719), as well as a possibility of recovery, separation of the coagulant and its re-use in drinking water treatment.

The aim of the research was to improve the Sušica source surface water treatment especially through coagulation and flocculation processes, to reduce chemical dosing amounts and generated sludge amounts, as well as to evaluate sludge quality, treatment and application. Instead of piling up waste by being taken to a landfill (used as land breeder), the generated sludge from Sušica will be converted into compost for growing medicinal herbs as a permanent solution after its treatment (toxic metal removal by zeolites as the fastest removal method and conditioning sludge).

The same strategy is intended to be applied to the surface water sludge from the Djetinja river, accumulated in Vrutci Lake, if sludge is not hazardous. But if the quality of surface water is deteriorating because the concentration of blue-green algae increases, the so-called cyanobacterial blooming occurs and sludge becomes dangerous, loaded with cyanotoxins, different strategy must be applied. 


\section{The experimental part}

Within the experimental part, some standard methods were used and some were developed as "new" ones for the analysis of the most useful physico-chemical and biological parameters for surface water, treated water and sludge: turbidity, $\mathrm{pH}$, electroconductivity, $\mathrm{KMnO}_{4}$ consumption, total organic carbon (TOC), total Kjeldalh nitrogen (TKN) phosphates, and chlorophyll a,b,c (biological parameter). The microbiological parametres were determined by standardised methods. These parameters are "common" for achieving the higher objective of respecting green environmental chemistry principles, assessing the management of the process of coagulation and flocculation with aluminum sulphate (or polyaluminum chloride) and polyectrolyte during the removal of natural organic matter (NOM), inorganic matter, pollutants, metals and sludge. Crops are estimated to be capable of growing on sludge converted to compost, but only after toxic metal overrange reduction and maturation. The investigated biological parameters were: phytoplankton, qualitative and quantitative, Chlorophyll a, b, c, nematodes, and zooplankton. The microbiological parameters were: total coli, fecal coli, fecal enterococci, and the total number of aerobic mesophiles.

\section{Reagents}

The chemicals of p.a. purity or ultra pure, of the world's most trusted manufacturers, were used.

Al strip, 99.997\%, Merck, Darmstadt, Germany.

Hydrochloric acid , $\mathrm{HCl}, 36,5-38 \%$, p.a, J.T.Baker, USA.

Sulphuric acid, $\mathrm{H}_{2} \mathrm{SO}_{4}$, p.a, $98 \%$, Fisher, USA.

Aluminum by the Eriochrome Cyanine method reagent set contains ECR-20 Reagent, Hexamethylenetetramine Buffer Reagent F20 and ECR Masking Reagent Solution, Hach, USA.

Ultra pure water, UPW voda, TOC $\leq 0.1 \mathrm{mg} / \mathrm{l}$, Sigma Aldrich, USA.

Potassium permanganate, $\mathrm{KMnO}_{4}$, p.a., Merck, Darmstadt, Germany.

The reagent stock solution is a concentrated mixture of phosphoric acid and ammonium persulphate, Hach, USA.

Nickel, metal pieces, $99.995 \%$, Merck, Darmstadt, Germany.

Lead, metal pieces, 99.995\%, Merck, Darmstadt, Germany.

Chromium, metal pieces, 99.995\% , Merck , Darmstadt, Germany.

Hydrochloric acid $\mathrm{HCl}, 30 \%$, suprapure, Merck, Darmstadt, Germany. 
Oxalic acid, $\mathrm{H}_{2} \mathrm{C}_{2} \mathrm{O}_{4} \times 2 \mathrm{H}_{2} \mathrm{O}$, p.a. Reagecon, Ireland.

Nitrogen, gas, 5.0, without $\mathrm{CO}_{2}, 200$ bar, Messer, Serbia. France.

Sodium Hydroxide, $\mathrm{NaOH}$, p.a., granules, Carlo Erba Reagents,

Boric acid, powder, p. a., Carlo Erba Reagents, France.

Tahiro indicator, Carl Roth, Germany.

The stock solutions: The stock solution of Al chloride $0.1 \mathrm{~mol} / \mathrm{L}$ was prepared by dissolving the shredded aluminum strip, weighing $0.53974 \mathrm{~g}$ with $5 \mathrm{ml} \mathrm{HCl}$ and $1-2 \mathrm{ml}$ redistilled water, with heating in a sand bath for several hours. The solution was dilluted with bidistiled water up to the $1 \mathrm{dm}^{3}$ mark of the volumetric flask. The solution concentration was precisely determined by the gravimetric analysis, so the concetration of Al was $0.1020 \mathrm{~mol} / \mathrm{L}$.

The stock solution of $\mathrm{Ni} \mathbf{0 . 1} \mathrm{g} / \mathrm{L}$ was obtained by dissolving $.0 .1 \mathrm{~g}$ of $\mathrm{Ni}$ pieces in $10 \mathrm{ml}$ of $\mathrm{HNO}_{3}$ conc. acid, oxide removed and cooled down. Then the solution was dilluted with bidistiled water up to the $1 \mathrm{dm}^{3}$ mark of the volumetric flask.

The stock solution of $\mathbf{P b} \mathbf{0 . 1} \mathrm{g} / \mathrm{L}$ was obtained by dissolving $0.1 \mathrm{~g}$ of $\mathrm{Pb}$ in $10 \mathrm{ml}$ of concentrated nitric acid, after dissolution, evaporated to dryness and then redissolved with redistilled water up to the $1 \mathrm{dm}^{3}$ mark of the volumetric flask.

The stock solution of $\mathrm{Cr} \mathbf{0 . 1} \mathbf{g} / \mathrm{L}$ was obtained by dissolving $.0 .1 \mathrm{~g}$ of $\mathrm{Cr}$ in $10 \mathrm{ml}$ of concentrated $\mathrm{HCl}$ acid; after cooling, the solution was dilluted with bidistiled water up to the $1 \mathrm{dm}^{3}$ mark of the volumetric flask.

$\mathrm{KMnO}_{4}$ standard solution $(\mathbf{0 . 0 2 M})$ was prepared by dissolving $3.160 \mathrm{~g} \mathrm{KMnO}_{4}$ in $200 \mathrm{ml}$ of redistilled water, supplemented up to the 1 $\mathrm{dm}^{3}$ mark of the volumetric flask. It is stored in a dark bottle.

The standard solution of oxalic acid $(0.1 \mathrm{M})$ was prepared by dissolving $6.303 \mathrm{~g}$ of oxalic acid with a little of redistilled water, added 50 $\mathrm{ml}$ of sulfuric acid $(1: 3)$ to conserve and dilluted with bidistiled water up to the $1 \mathrm{dm}^{3}$ mark of the volumetric flask.

The working solutions were made by diluting the stock or standard solutions with bidistiled water.

Instruments

1. Hach $2100 \mathrm{~N}$ turbidimeter for turbidity measurement with calibration standards based on formazionic polymer: $<0.1$ NTU, 20 NTU, 200 NTU and 1000 NTU, Hach.

2. Stirrer, Velp scientifica, $\mathrm{T}$ range $0-350^{\circ} \mathrm{C}$ and rpm range: $0-1500$ 
3. $\mathrm{pH}$-meter, Infolab WTW, with glass electrode, $\mathrm{pH}$ range 0-14, resolution $0.01 \mathrm{pH} ; \mathrm{pH}$ accuracy $\pm 0.01 \mathrm{pH}$ units, with buffers for calibration $\mathrm{pH} 4.00$ (phthalate), $\mathrm{pH} 7.00$ (phosphate), pH 9.00 (borate) Hach

4. Conductometer, HQ $440 \mathrm{~d}$, multi with $\mathrm{CRM}$ standard $100 \mu \mathrm{S} / \mathrm{cm}$ $\pm 1 \mu \mathrm{S} / \mathrm{cm}, \mathrm{NIST}$

5. Automatic burette, Tirette $50 \mathrm{ml}$, Class A, Brand,

6. Spectrophotometer, Lange DR 6000, Hach, with Hach software, vers. 11 , with UV and VIS lamp, $1 \mathrm{~cm}$ and $5 \mathrm{~cm}$ quartz and glass cells, for the analysis of true and apparent water color (in Co-Pt units) and $\mathrm{Al}$ concentration (using manufacturer's method with commercial reagents and methods with "classical" solutions of eriochrome-cyanine and aluminon, after forming calibration curves). The compared results of different methods showed good agreement. The instrument was also used for the determination of UV extinction at $254 \mathrm{~cm}^{-1}$, chlorophyll $a, b$, and $c$ (where absorbances were measured on two wavelengths: 665 and $750 \mathrm{~nm}$ ), nitrogen compounds and ortho-phosphates and total phosphorous .

7. TOC analyzer. (total organic carbon analyzer) Qbd 1200 with autosampler, Hach, with a UV lamp, a burette for persulphate reagent addition and a non-dispersive IC detector, NDIR. The measuring range is from $0.4 \mu \mathrm{g} / \mathrm{L}$ to $100 \mathrm{mg} / \mathrm{L}$, with the accuracy of $3 \%$, calibration standard, manufacturer's cuvettes, and nitrogen gas 5.0.

8. Gerhardt analytical system for the determination of total nitrogen from different matrix (water, sludge, food) by Kjeldah (with three units Gerhardt Turbotherm with 4 digestion cells, for sample destruction, Turbosoq, centrifugal rinse for inorganic gases and vapors and Gerhardt Vapodest 200, unit for distillation and a volumetric titration burette of the resulting solution after digestion and distillation. The reference material (RM) solution is prepared of histidine nitrogen, conc. $5 \mathrm{mg} / \mathrm{l}$. The sample with 2 drops of Tahiro indicator is titrated with $0.1 \mathrm{M}$ hydrochloric acid until the color changes from slightly green to pink.

9. Laboratory mini plant, Jar Test FC6S, Velp Scientifica, consisting of four $2 \mathrm{dm}^{3}$ jars with supernatant sample taps, with programmable speed and time settings and a possibility to adjust coagulant and flocculant doses.

10. ICP-OES spectrometer, ICAP Pro for metal concetration analysis, $\mathrm{Rf}$ generator, $27 \mathrm{MHz}, 167-852 \mathrm{~nm}$ wavelength range, $7 \mathrm{ppm}$ resolution, multi-element analysis, $99.999 \%$ argon used as carrier, nebulization and plasma forming gas, with a nebulizer, a torch (burner), 
quartz or glass, depending on the acids used for sample preparation, Thermo Scientific.

\section{Sample preparation}

a) The procedure for raw surface water sample preparation

A preferably fresh raw water sample is taken in a specified volume in accordance with the method. Some samples were filtered through $0.45 \mu \mathrm{m}$ filter before measuring.

b) Procedure for sludge sample preparation

$1 \mathrm{dm}^{3}$ of sludge is taken, the liquid part is decanted and the rest dried at $104^{\circ} \mathrm{C}$ for 5 hours. Most analyses were done from dry sludge calculated for the $\mathrm{mg} / \mathrm{kg}$ weight, and a few analysis were done from decanted liquid.

c) Procedure for compost sample preparation

$1 \mathrm{~kg}$ of compost is taken and put to dry till constant mass for most analyses and the results are calculated for the weight in $\mathrm{mg} / \mathrm{kg}$. Sampling and sample preparation were carried out in accordance with the appropriate standards (SRPS or EPA).

d) Kjedalh total nitrogen is determined by a modified method adapted for this type of samples using standard SRPS ISO 1871:2013 (Institute for Standardization of Serbia, 2013) and Gerhard methods for total nitrogen in water, adapted for given samples and conditions, with all tests for method validation.

e) TOC/DOC is determined by standard SRPS ISO 8245, 2007 (Institute for Standardization of Serbia, 2007) adjusted for water samples and for dissolved organic carbon (DOC) from sludge, where samples are filtered through a $0.45 \mu \mathrm{m}$ size filter. The method was developed by validation principles.

f) Aluminum concetrations in surface water, water from different stages of the treatment process, waste water, residual, and sludge were determined spectrophotometrically. The method with commercial reagents was compared with classical methods with solutions of eriochrome cyanine and hexamethylenetetramine, as well as with aluminon, with six standard solutions. The calibration curve equation was $C=0.015+0.8217 A$. The linearity coefficient was $R^{2}=0.9997$. The three 
compared aluminum quantification methods give results in very good agreement, no matter the sample matrix.

\section{Water Treatment Plant - Chemicals}

The following chemicals of technical purity were used in the water treatment: Coagulant $\mathrm{Al}_{2}\left(\mathrm{SO}_{4}\right)_{3} \times 18 \mathrm{H}_{2} \mathrm{O}$, class A, Marking Itd, or $\mathrm{Al}_{\mathrm{n}} \mathrm{Cl}_{(3 n-}$ ${ }_{m)}(\mathrm{OH})_{m}$, Impuls hemija Itd, used occasionally, Polyelectrolyte anionic, Settafloc AP -17, SNF s.a.s

\section{Water Treatment Plant - Part for coagulation and flocculation}

I * Saturator for aluminum sulphate stock solution preparation, with centrifugal pumps for mixing a solution, Technique KB, Belgrade

* Pools, where the stock solution of Al-sulphate dilutes with water, after aging, up to a required concentration, and the pumps (pistonmembrane) for pumping the Al-sulphate solution, Technique $\mathrm{KB}$, Belgrade

* Dosage unit for Al-sulphate with the ProMinent pump Heidelberg, Germany, power $0.55 \mathrm{~kW}$, and a dosing speed of $1033 \mathrm{I} / \mathrm{h}$ with an Omron frequency control for speed adjustment

II * Flocculation Part with Prominent instruments for making a solution of polyelectrolyte and dosing it into water, and with spectra type Prominent pumps with a capacity of $650 \mathrm{~L} / \mathrm{h}$. The preparation of a solution of polyelectrolyte with ultrasonic control of the added polyelectrolyte amount, with a Siemens control unit and 3-speed flocculation mixers: a small mixer rated at $3 \mathrm{~kW}, 11 \mathrm{rpm}$, a medium one at $2.2 \mathrm{~kW}$ and $5.7 \mathrm{rpm}$ (turnover per minute) and a large mixer driven by an engine of rated power of $1.1 \mathrm{~kW}$, with $2.7 \mathrm{rpm}$, Strojna, Maribor

III * Precipitator automated and cotrolled by SCADA software, ver 2.0, for remote and process control; sludge discharge valves towards the lagoons, where closing and opening of the valves is carried out from the Schneider Electric substation

\section{Results and discussion}

The paper deals with the treatment of surface water and the amount of sludge generated in the case of using surface water from the Sušica river, before and after technically-technologically upgrading the water treatment plant. The treatment of raw water also includes ozonization and filtration processes with sand, quartz filters and activated carbon filtration. Water treatment also includes disinfection with chlorine gas. 
In the extended physical-chemical analysis of the surface water from the Sušica sources (Small and Large Source), the following was determined: $0.026 \mathrm{mg} / \mathrm{l}$ of aluminum, $0.027 \mathrm{mg} / \mathrm{l}$ of iron, $0.013 \mathrm{mg} / \mathrm{l}$ of barium, and $0.079 \mathrm{mg} / \mathrm{l}$ of strontium. The concentration of phosphorous is $0.015 \mathrm{mg} / \mathrm{l}$ while that of boron is $0.04 \mathrm{mg} / \mathrm{l}$. The quality of raw water is continuously monitored to assess which chemicals (and how much of them) should be added to produce hygienically safe drinking water. During the jar tests at the laboratory conditions, the coagulant and flocculant doses were adjusted, in accordance with the surface water quality and the optimal speed for stable flocule formation and then transferred to the water treatment plant. In the flocculation section in the water plant, the 3-speed mixer helped to better manage the process. The pollutants removed by coagulation \& flocculation are: turbidity (removal efficiency over 95\%), alkali metal ions (calcium, removal efficiency $29 \%$ ), dissolved silica, bacteria, algae, apparent, true Pt-Co dye, organic compounds, oxidized iron, manganese, clay particles, and aluminum ions (Nishat Ashraf et al, 2018, pp.187-199).

These compounds undergo alkaline hydrolysis in the alkaline medium, producing positively charged, insoluble, voluminous hydroxides. The hydroxides have a large adsorption surface and attract oppositely charged (negative) colloids, thus neutralizing their charge (aluminum ions). During flocculation, polyelectrolytes increase the volume and cohesion properties of colloidal particles, accelerate coagulation and improve its effects.

The presented graphs show the dose dependence of aluminum as a coagulant on the amount of raw water discharged to the water plant treatment during 2017 when water treatment was still classical, and in 2018, when water treatment was improved. In both cases, raw water comes from the Sušica sources.

\section{Sušica River, classical method of water treatment - February 2017}

The amounts and doses of coagulants and flocculants depend on the amount of water entering the plant and the quality of raw water which depends on climatic conditions (such as season, temperature, rainfall, snow, global warming, and imbalance in aquatic ecosystems). In the tables given below, the parameters present the quality of surface raw water in the selected month. Using this data, jar tests are used to adjust coagulant and flocculant doses as efficiently as possible (Nishat Ashraf et al, 2018, pp.187-199). The goal is to compare the amounts of sludge generated during 2017 and 2018 and to evaluate a possibility of its 
application (for composting) in the case of the surface water from the Sušica sources. The water treatment plant doubled its capacity after the reconstruction. Owing to the improvement in the key processes, i.e. in coagulation and flocculation, the amount of waste sludge was reduced. Then, after checking its quality and after dehydration and removal of toxic compounds, sludge could be applied in agriculture.

Table 1 - Results of physico-chemical analysis of surface water, February 2017.

Таблица 1 - Результаты фризико-химических анализов поверхностных вод в фреврале 2017 года

Табела 1 - Резултати фризичко-хемијских анлиза површинске воде у фебруару 2017. године

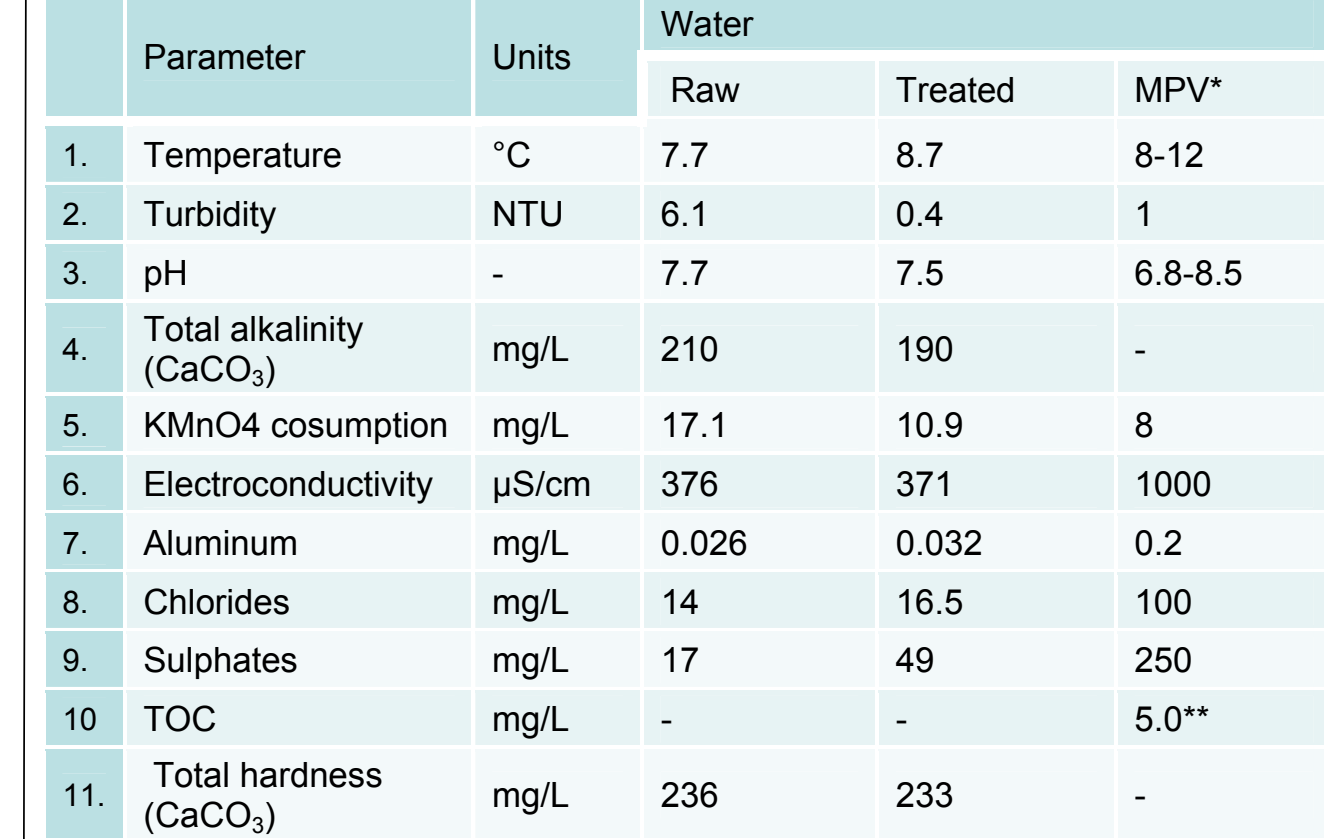

$\mathrm{MPV}^{*}$ - refers to II-III surface water class - type 6, Official Gazette of the Republic of Serbia, No 74/2011, Regulations on the parameters of the ecological and chemical status of surface waters and the parameters of the chemical and quantitative status of groundwaters.

$\mathrm{MPV}^{* *}$ - maximum permissiblle (concentration) value, according to the Official Gazette of the SRJ, No 42/1998, 44/1999, Official Gazette of the Republic of Serbia $28 / 2019$, Rulebook on the Hygienic Safety of Drinking Water.

During the winter period, the turbidity of the Sušica source water increased 6 times over the MPV and the consumption of $\mathrm{KMnO}_{4}$ 
increased up to 2 times, which indicates the burden on natural organic matter. In order to make this water hygienically correct, it was treated with chemicals. The dosage of Al-sulphate and polyelectrolyte, as a function of the amount of inlet water per day, is shown graphically for February 2017, Figure 3a. The coagulant dose is low because the water was of average quality from the physico-chemical point of view (average and uniform total carbonate hardness, i.e total alkalinity for the Sušica source) and from the biological point of view. This water periodically requires more chemicals because the spring is variable due to rainfall and water temeperature that cause variations of biological species and their abundance. The microbiological Sušica water status during February 2017 required higher doses of disinfectants, because Coliform, total coliform bacteria of fecal origin and total aerobic mesophilic bacteria were above the maximum prescribed. The nitrate concentration was 7.2 $\mathrm{mg} / \mathrm{l}$. The used coagulant was aluminum sulphate that binds efficiently with pollutants.

The treatments of raw water in February 2017 and February 2018 are compared and graphically presented as a relationship of the doses of Al- sulphate, i.e polyelectrolyte as a function of the amount of raw water per day, Figures 3a, 3b.

Turbidity indicated an increase in suspended matter: clay, silt, wellarranged organic and inorganic particles. Phytoplankton and microorganisms and ranged from 2.9 to 6.1 , so the doses of Al-coagulant and polyectrolyte were higher for medium hard Sušica source water, between 5 and 7 days of February 2017. After the treatment of the Sušica water of this quality, drinking water, waste water and sludge were produced in the plant. In February, out of the total amount of raw water of $480,418 \mathrm{~m}^{3}$ introduced into the water treatment plant, the amount of generated sludge was $6,586 \mathrm{~m}^{3}$. During the autumn and winter months, especially in November and December 2017, more sludge was generated because turbidity and organic and inorganic pollutants in water increase due to low water temperatures of $7.7{ }^{\circ} \mathrm{C}$ which causes the solubility of gases (oxygen and carbon dioxide). So, oxygen increases in water, due to the increased degradation of organic matter and the development of living organisms, as well as the increased photosynthetic processes, which is also confirmed by the increased $\mathrm{KMnO}_{4}$ consumption (atmospheric pressure also influences the rise in oxygen content). Based on Henry's law, decreasing temperature leads to an increase in the solubility of gases in water $\left(\mathrm{O}_{2}, \mathrm{CO}_{2}\right)$ as well as in turbidity (due to more rainfall). At lower $\mathrm{T}$, the coagulation process is slower and with less efficiency. 


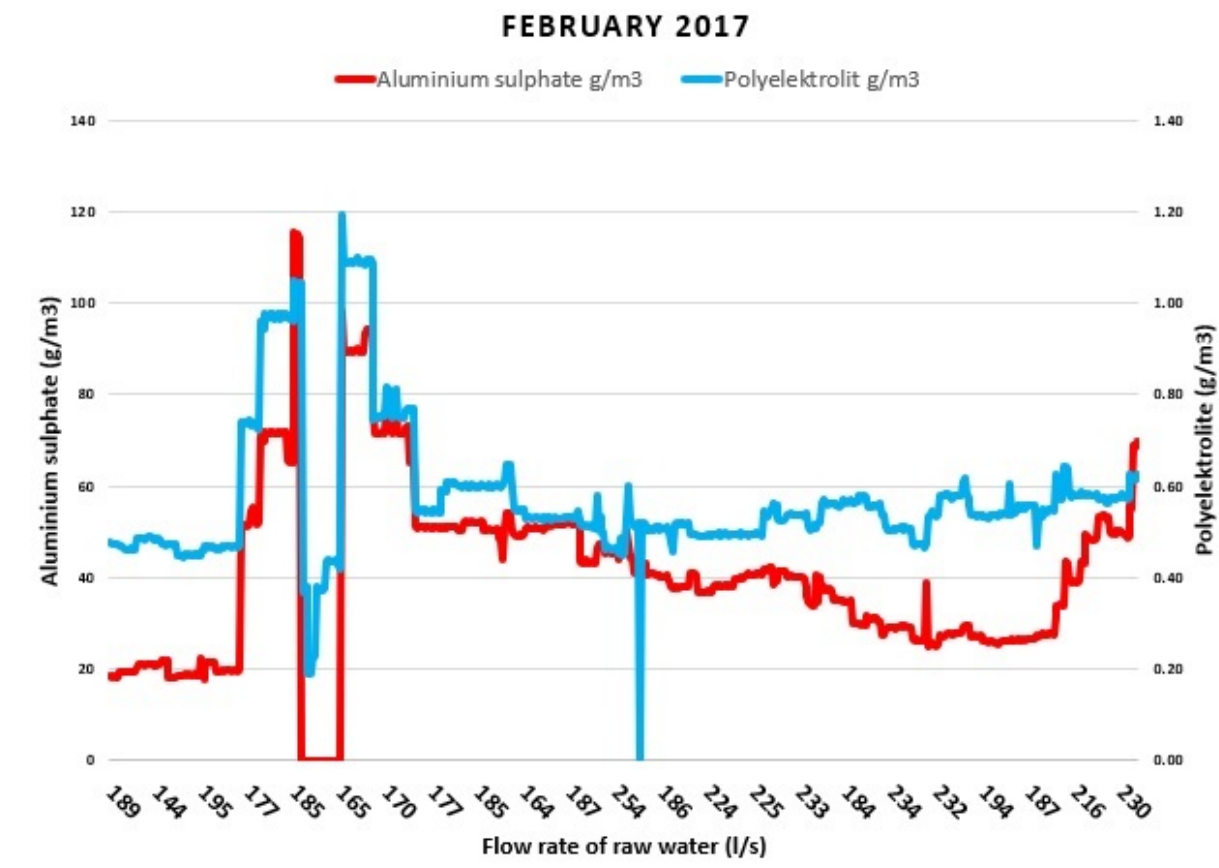

Figure 3a-Dependence of the concentration of added aluminum sulphate and polyelectrolyte on the flow rate of raw water during February 2017

Puс. За - Взаимозависимость концентрации добавленного сульфата алюминия и полиэлектролита и протока сырой воды в течение фревраля 2017 года

Слика За - Међусобна зависност концентрације додатог алуминијум сулфата и полиелектролита од протока сирове воде у току фебруара 2017. године

Sušica River, after the water supply plant reconstruction February 2018

During February 2018, the same Sušica source water was used, but the flocculation and deposition part of the water treatment plant was improved after reconstruction, so it was expected that the amount of sludge generated would be lower as the flocculation process was improved with 3 stirring speeds and lamellar precipitators as well. However, during February 2018, the facts were opposite to the expectations, because the quality of raw water was "above" the technical improvement of the water plant functioning (physico-chemical characteristics, microbiological and biological status deteriorated). Figure $3 \mathrm{~b}$ shows that the amount of added polytherolite increased almost twice, $1.2 \mathrm{~g} / \mathrm{m}^{3}$ in comparison to February 2017. Raw water coloration was 10 Co-Pt units, effectively removed by the coagulant. The coloration was 
most likely derived from nutrient enrichment of water, eutrophication, at low water temperatures which stimulate the production of algae and also increase turbidity (1.6 NTU), increased $\mathrm{KMnO}_{4}$ consumption and nitrates up to $5.2 \mathrm{mg} / \mathrm{l}$. Algae contain chlorophyll in their cells, determined as chlorophyll a, b, and c on the DR 6000 UV-VIS spectrophotometer. In cold water, more decomposed organic matter accumulates at greater depths, thus leading to a reduction in the quality of fish life conditions. An increased amount of polyelectrolyte up to 2 times, caused by the deterioration of raw water quality, for almost the same amount of water inlet of $473,418 \mathrm{~m}^{3}$, generated an increased amount of sludge up to $7,274 \mathrm{~m}^{3}$ when compared to February 2017 (when it was $6,586 \mathrm{~m}^{3}$ ). The microbiological status indicated that total coliform bacteria were over 161 and that coliform bacteria of fecal origin were present in the number higher than 161; streptococci of fecal origin and Citrobacter spp were also isolated - therefore, water purification and desinfection were intensified.

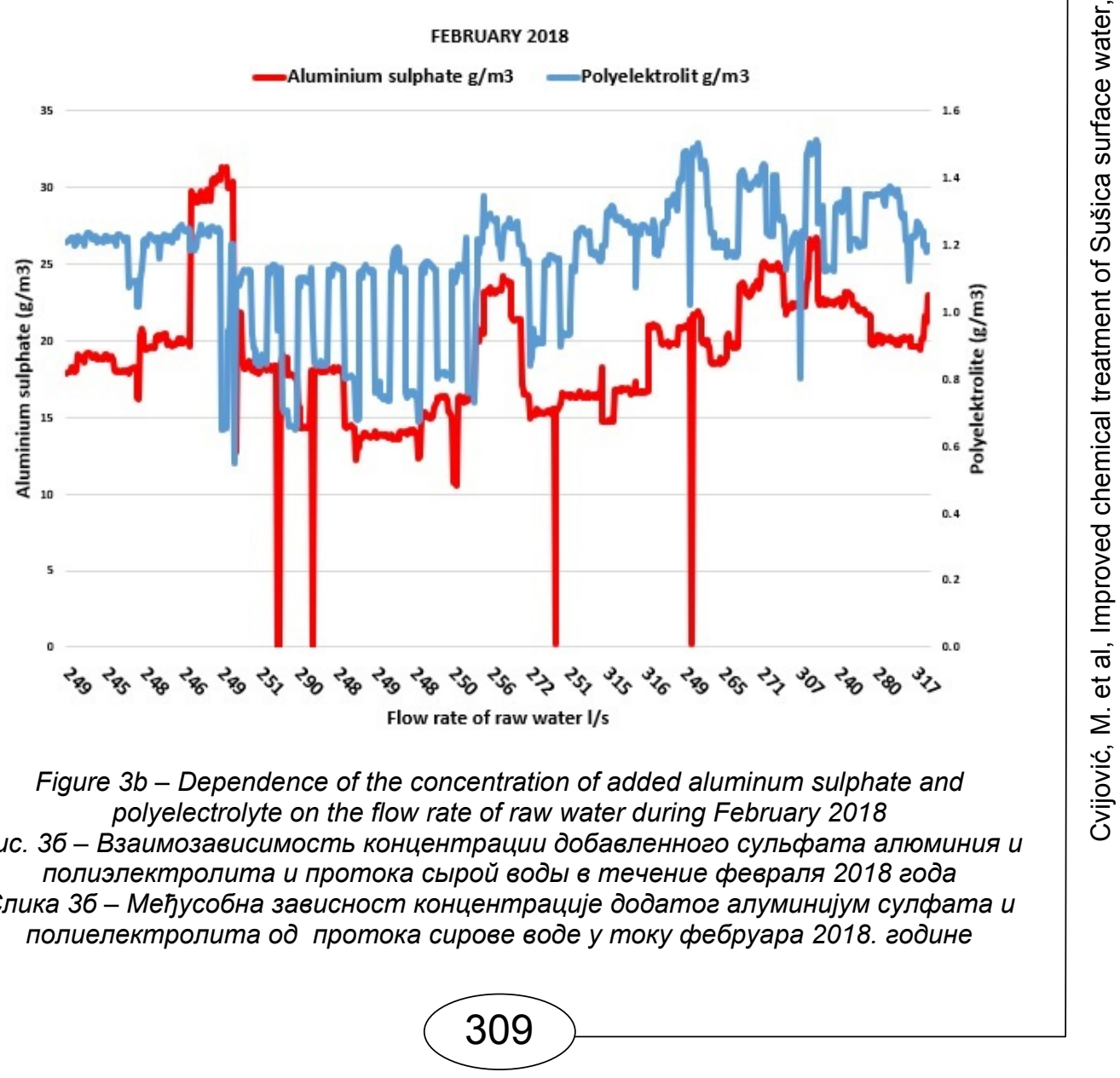




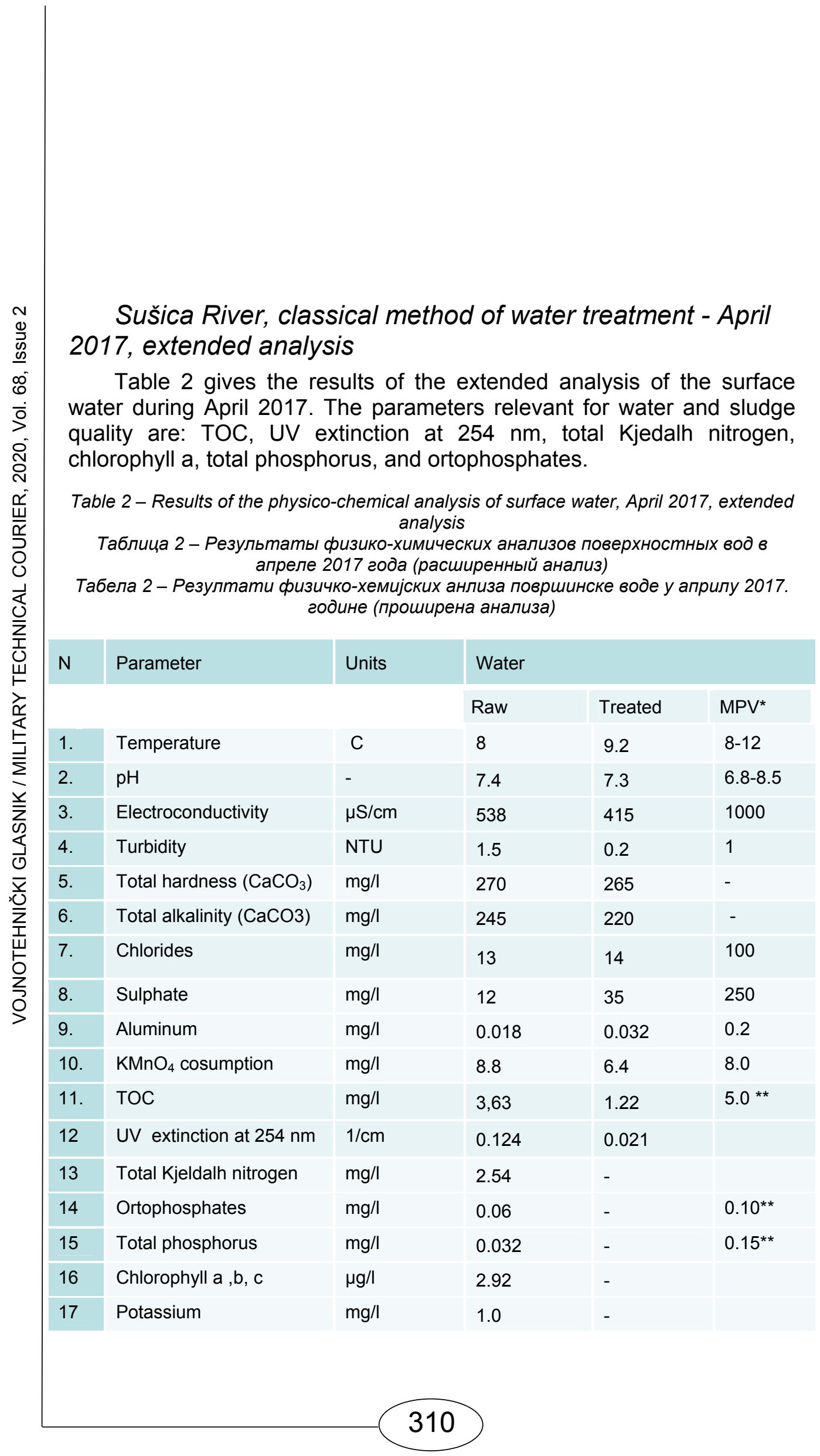


These parameters and metals are important in the compost quality evaluation. Some instrumental methods were developed on the basis of standards, adapted and improved, as well as tested according to the principles of accredited methods (repeatability, accuracy, potential sources of errors tested, limit of detection, limit of quantification, and measuring uncertainty).

The determination of total organic carbon (TOC) is the most valid indicator of organic matter in surface water, because there is a complete degradation of a sample caused by the reagent stock solution, i.e. a concentrated mixture of phosphoric acid (to aid in removal of $\mathrm{CO}_{2}$ from solution) and ammonium persulphate (to aid in oxidizing organic compounds) and UV radiation. The TOC method was developed for water samples and used for sludge, as well. Firstlly, the calibration curve was constructed after measuring the peak area (of total organic carbon) as a function of the TOC concentration in the calibrated standards. Every calibration standard was with 3 times repeated measurement, for the concentration range from 1000 to $5000 \mathrm{ppb}$. The calibration curve equation is $Y=9.23 x+25.92$. The linearity coefficient is $R^{2}=0.9997$. Blank was analyzed before each analysis. Tests for reproducibility, precision, as well as limit of detection and limit of quantification were done. Distilled, redistilled water and ultra pure water (upw) were analyzed before the samples of interest. There were some variations with distilled and redistilled water regarding the TOC results. When distilled, redistilled and ultra pure water were analyzed, it was observed that distilled water flowing through the ion exchange resin showed higher and variable values of TOC, because the resin was saturated, impured. The impurity of resin was noticed to affect the TOC results, as well as the electroconductivity results for distilled water. This problem was solved by replacing the ion exchange resin.

The TOC samples of surface water and sludge as well as the samples from the water treatment process were randomly analyzed with repetition, day by day. The effects of larger diameter particles present in water during treatment with coagulants and flocculants were also analyzed. The formed particles of aluminum sulphate and polyelectrolyte with impurities from the precipitate, over $100 \mu \mathrm{m}$, (where the concentration of $\mathrm{Al}$ was in a range of $0.78-0.92 \mathrm{mg} / \mathrm{l}$ ) had difficulty in degrading by the action of UV radiation and a mixture of phosphoric acid and ammonium persulphate reagent. On the contrary, during the total organic carbon analysis, the degradation of the surface fresh water samples was easy and repeatable. Besides the contamination of distilled water, redistilled water can be contaminated with $\mathrm{CO}_{2}$, if a vessel 
remains open. Other sources of contamination have also been investigated. After removing a contamination source, the methods were rigorously tested up to the level of in-house validation and then accepted

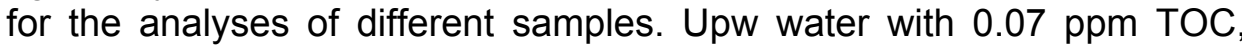
redistilled water, and destilled water were first measured before other samples. Some samples were tested many times and after receiving valid results, they were conserved and accepted as an internal standard.

The literature data has shown similar problems with contamination and variable TOC results for destilled water chosen by other researchers (Meyers, 1998).

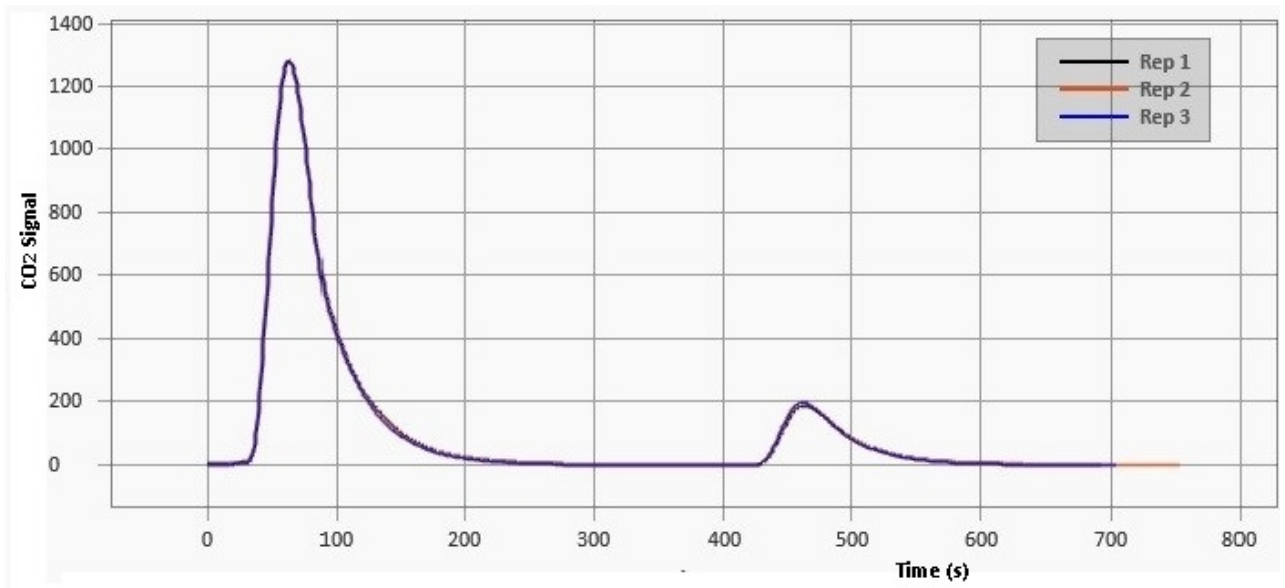

Figure 4-TOC spectrum of surface water: the left high peak belongs to total inorganic carbon (TIC), the lower right one belongs to total organic carbon (TOC)

Puc. 4 - Спектр TOC поверхностных вод: левый верхний пик относится к общему неорганическому углероду (TIC), нижний правый пик относится к общему органическому углероду (TOC)

Слика 4 - Спектар ТОЦ површинске воде, леви виши пик припада укупном неорганском угљенику (ТИЦ), а нижи десни пик укупном органском угљенику (ТОЦ)

The TOC method is developed by using standard SRPS ISO 8245 2007 (Institute for Standardization of Serbia, 2007) as basic literature, after many tests, improvements, and statistical evaluations for different matrix samples.

Chlorophyll a,b,c is an indicator of the biological status of raw surface water (photosynthesis and present algae). Chlorophyll a,b,c was determined spectrophotometrically by a DR 6000 device, as the difference of the measured absobances at 750 and $665 \mathrm{~nm}$, from an ethanol solution. This method is validated with some improvements. The comparative method is formed on the basis of the standard and the 
chlorophyll calculated by a formula as a difference in measuring absorbance at 634 and $675 \mathrm{~nm}$ and from a methanol and acetone solution, as well. The results are in good agreement, and in accordance with the results for similar samples, published by R.J. Ritchie (Ritchie, 2006, pp.27-41).

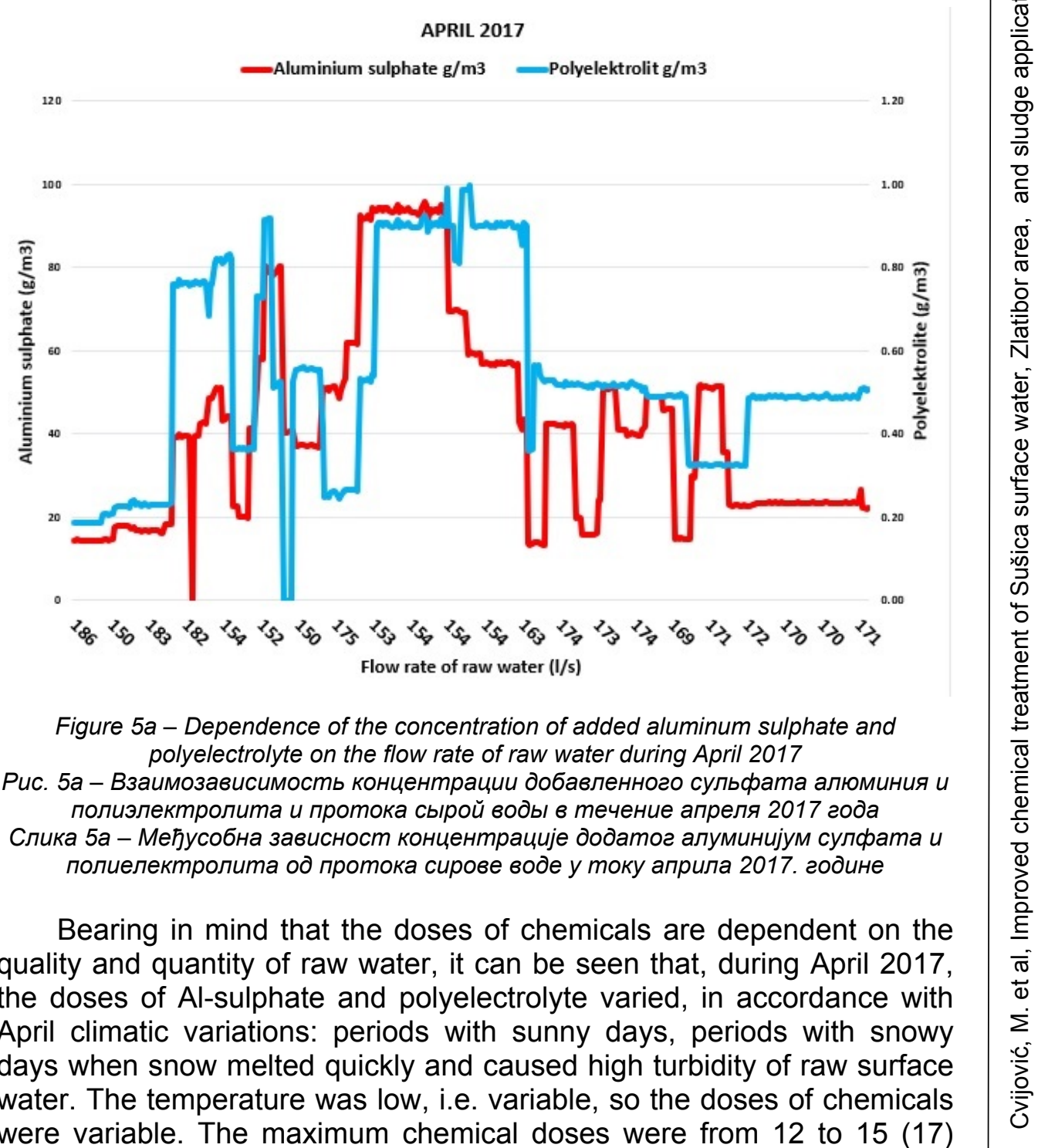




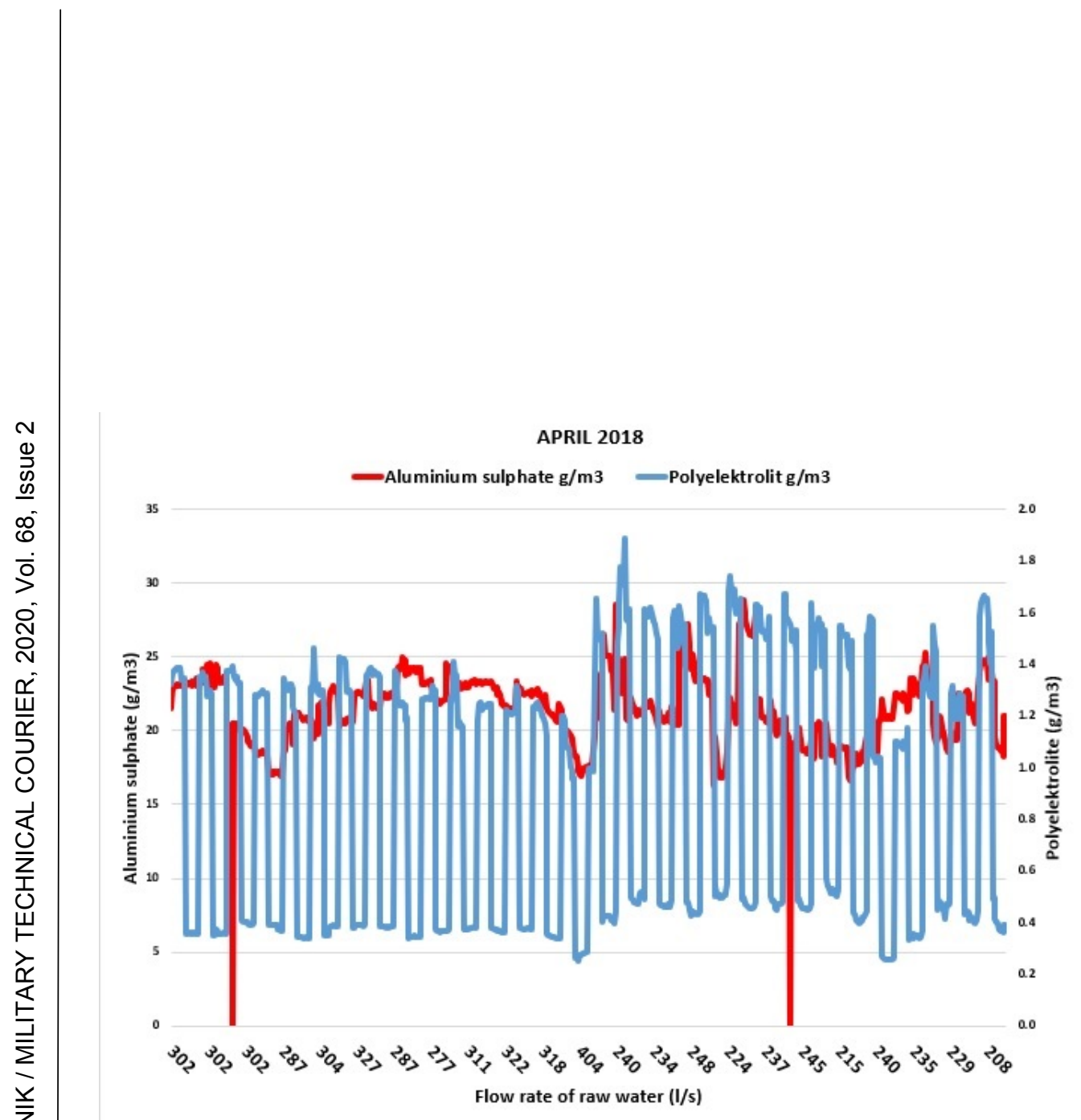

Figure $5 b$ - Dependence of the concentration of added aluminum sulphate and polyelectrolyte on the flow rate of raw water during April 2018

Puс. 56 - Взаимозависимость концентрации добавленного сульфрата алюминия и полиэлектролита и протока сырой воды в течение апреля 2018 года

Слика 5б - Међусобна зависност концетрације додатог алуминијум сулфата и полиелектролита од протока сирове воде у току априла 2018.године

During April 2018, the average doses of Al-sulphate were $24 \mathrm{~g} / \mathrm{m}^{3}$, and those of polyelectrolytes were $0.4-1.4 \mathrm{~g} / \mathrm{m}^{3}$. The chemical doses were less variable because both climatic and other parameters were more constant. The amount of $4,977 \mathrm{~m}^{3}$ of sludge was produced out of $681,193 \mathrm{~m}^{3}$ of raw water during april 2018 , which is about 2 times lower than in the same month during 2017. A smaller amount of sludge was generated in the reconstructed plant as expected. The microbiological status indicated that the number of coliform bacteria of fecal origin was over 24 in $100 \mathrm{ml}$, above the maximum allowed value. E. Coli was also found.

During summer, July of 2017 and 2018, the water temperature increased and ranged between $13-14^{\circ} \mathrm{C}$, contributing to a decrease in the solubility of oxygen and other gases in water according to Henry's law. The reduction of oxygen concentration inhibits oxidative processes, and, consequently, degradation of organic substances and development 
of living organisms in surface water. This caused a decrease in the $\mathrm{KMnO}_{4}$ consumption. Therefore, the average doses of chemicals in summer are reduced as well as the amount of sludge generated in summer 2017 and 2018.

A detailed physico-chemical analysis of sludge collected during 2017 and 2018 was carried out and some data is presented in Table 3.

Table 3 - Results of the physico-chemical analysis of sludge Таблица 3 - Результаты фризико-химических анализов ила

Табела 3 - Резултати физичко-хемијских анализа муља

\begin{tabular}{|l|l|l|l|l|}
\hline $\mathrm{N}$ & Parameter & Units & Value & MPV*** \\
\hline 1. & Humidity & $\%$ & 87.18 & - \\
\hline 2 & Solids content & $\%$ & 12.82 & \\
\hline 3 & Total Kjeldah nitrogen & $\mathrm{mg} / \mathrm{kg}$ & $9.6^{*}$ & \\
\hline 4. & Phosphorous & $\mathrm{mg} / \mathrm{kg}$ & 697 & \\
\hline 5. & TOC /DOC & $\mathrm{mg} / \mathrm{kg}$ & 274 & $<20$ \\
\hline 6. & C/N ratio & $\mathrm{w} / \mathrm{w}$ & 28.5 & - \\
\hline 7. & Potassium & $\mathrm{mg} / \mathrm{kg}$ & 297 & - \\
\hline 8. & Aluminum & $\mathrm{mg} / \mathrm{kg}$ & 72200 & 25 \\
\hline 9. & Copper & $\mathrm{mg} / \mathrm{kg}$ & 8.9 & 5 \\
\hline 10. & Total Chromium & $\mathrm{mg} / \mathrm{kg}$ & 69,5 & 20 \\
\hline 11. & Nickel & $\mathrm{mg} / \mathrm{kg}$ & 169 & 5 \\
\hline 12. & Lead & $\mathrm{mg} / \mathrm{kg}$ & 5.7 & \\
\hline
\end{tabular}

MPV*** - Official Gazette of the Republic of Serbia, No. 56/2010, 93/2019, Regulation on categories, testing and classification of waste, Attachment 10

$\mathrm{C} / \mathrm{N}=$ Carbon Content $\mathrm{mgkg}^{-1} /$ Nitrogen Content $\mathrm{mgkg}^{-1}=\mathrm{TOC} \mathrm{mgkg}^{-1} / \mathrm{TKN} \mathrm{mgkg}^{-1}$

As the maximum permissible values were exceeded for $\mathrm{Ni}, \mathrm{Pb}$, total $\mathrm{Cr}$, and toxic metals, this sludge needed treatment for the removal of these metals (Kerkez, 2014), especially if there is intention to use it in composting or postponement (land breeder). Aluminum should also be removed, regardless of the fact that it is not over the maximum permissible value since it is categorized as a detrimental metal. So, the sludge generated from the Sušica surface water should be used as compost, but only after metal removal with zeolites and maturation. The 
minimal conditions for composting are also tested in accordance with the Serbian legislation (Institute for Standardization of Serbia, 2017). An opportunity is thus provided to use treated sludge as a material for growing Coriandrum sativum. The medical effect of Coriandrum sativum is compared to the effect of ciprofloxacin, gentamicin and other antibiotics. It is useful as a spice plant and in cosmetics. In further work, this strategy should be applied to a treatment of the Djetinja (Vrutci Lake) surface water and its generated sludge.

\section{Conclusion}

The obtained results confirmed the next findings:

After the reconstruction of the water treatment plant, especially the lines for coagulation and flocculation, the quantity of the formed sludge decreased due to the technical plant improvements such as 3-speed strirrers during flocculation and one new polyelectrolite.

Before the reconstruction, the $\mathrm{pH}$-values were adjusted and doses of coagulants such as aluminum sulphate or polyaluminum chloride were based on jar testing every day. After the improvement of the water plant treatment, the addition of coagulants is better controlled, drinking water is, according to standards, "easily" received, and the amount of sludge is minimized.

The formation of "high-quality" floccules was more efficient when the system with three stirring rates was used.

The sludge formed during 2017 and 2018 contained metals such as $\mathrm{Ni}$, total $\mathrm{Cr}$, and $\mathrm{Pb}$, and they exceded their maximum permissible values. Therefore, the sludge treatment was required.

Eutrophication as a process of enriching water with nutrients results in increased organic compounds and primary production of aquatic plants. This increased organic content is bacterially decomposed, consuming available oxygen and affecting the development of other aquatic organisms. The nutrients-enriched water stimulates the production of algae, thereby increasing turbidity, water color and total organic carbon.

The quality of the Sušica surface water is strongly affected by season, water temperature, dissolved gasses $\left(\mathrm{O}_{2}\right.$ and $\left.\mathrm{CO}_{2}\right)$, level of rainfall, as well as living organisms in water.

The generated sludge quality is strongly affected by the quality of the Sušica surface water and the amount of water inlet to the water plant.

Generated sludge should be used as compost, but only after metal removal with zeolites and maturation. 
The minimal conditions for composting are also tested and provide the opportunity to use treated sludge as compost for growing Coriandrum sativum.

\section{References}

Aguilar, M.I., Sáez, J., Lloréns, M., Soler, A., Ortuño, J.F., Meseguer, V., \& Fuentes, A. 2005. Improvement of coagulation-flocculation process using anionic polyacrylamide as coagulant aid. Chemosphere, 58(1), pp.47-56. Available at: https://doi.org/10.1016/j.chemosphere.2004.09.008.

Christophoridis, C., Zervou, S-K., Manolidi, K., Katsiapi, M., MoustakaGouni, M., Kaloudis, T., Triantis, T.M., \& Hiskia, A. 2018.. Occurrence and diversity of cyanotoxins in Greek lakes. Scientific Reports, 8, 17877. Available at: https://doi.org/10.1038/s41598-018-35428-x.

Cvijovic, M., Di Marco, V., Traldi, P., Stankov, M.J., \& Djurdjević, P. 2012. Mass Spectrometric Study of Speciation in Aluminium-Fluoroquinolone Solutions. European Journal of Mass Spectrometry, 18(3), pp.313-322. Available at: https://doi.org/10.1255/ejms.1183.

Cvijović, M., Kilibarda, V., Jelikić-Stankov, M., Lazarević, I., Jakovljević, I. , Joksović, Lj., \& Đurđević, P. 2012. ESI-MS study of speciation in hydryzed aluminium chloride solutions. Journal of the Brazilian Chemical Society, 23(6), pp.1087-1097. Available at: https://doi.org/10.1590/S0103-50532012000600013.

Čudić, V., Stojiljković, D., \& Jovović, A. 2016. Phytoremediation potential of wild plants growing on soil contaminated with heavy metals. Archives of Industrial Hygiene and Toxicology, 67(3), pp.229-239. Available at: https://doi.org/10.1515/aiht-2016-67-2829.

Djurdjevic, P., Cvijovic, M., \& Zakrzewska, J. 2005. Aluminium(III) complexes of S-histidine: synthesis, characterization and potentiometric and spectroscopic study of solution equilibria. Journal of Coordination Chemistry, 58(17), pp.1615-1629,Available at: https://doi.org/10.1080/00958970500258807.

-Institute for Standardization of Serbia. 2007. SRPS ISO 8245, 2007. Water quality - Guidelines for the determination of total organic carbon (TOC) and dissolved organic carbon (DOC) [online]. Available at: https://www.iss.rs/rs/standard/?natstandard_document_id=16793\&is_print=1 [Accessed: 12 April 2020].

-Institute for Standardization of Serbia. 2013. SRPS ISO 1871:2013. Food and feed products - General guidelines for the determination of nitrogen by the Kjeldahl method [online]. Available at: https://www.iss.rs/en/standard/?national_standard_id=42530 [Accessed: 12 April 2020].

-Institute for Standardization of Serbia. 2017. SRPS Z.T1.100:2017. Specification for Composted Material [online]. Available at: https://www.iss.rs/rs/standard/?natstandard_document_id=60801.

Katsiapi, M., Moustaka-Gouni, M., Michaloudi, E., \& Kormas, K.Ar. 2011. Phytoplankton and water quality in a Mediterranean drinking-water reservoir (Marathonas Reservoir, Greece). Environmental Monitoring and Assessment, 181, pp.563-575. Available at: https://doi.org/10.1007/s10661-010-1851-3. 
Keeley, J., Jarvis, P., \& Judd, S.J. 2014. Coagulant Recovery from Water Treatment Residuals: A Review of Applicable Technologies. Critical Reviews in Environmental Science and Technology, 44:24, pp.2675-2719. Available at: https://doi.org/10.1080/10643389.2013.829766.

Kerkez, Đ. 2014. Potencijal upotrebe piritne izgoretine u tretmanu otpadnih voda i mogućnost njene dalje sanacije primenom imobilizacionih agenasa. Ph.D. thesis. Novi Sad, Serbia: University of Novi Sad, Faculty of Science (in Serbian) [online].

Available

at: http://nardus.mpn.gov.rs/bitstream/handle/123456789/1780/Disertacija.pdf?sequ ence=1\&isAllowed=y [Accessed: 12 April 2020].

Malik, Q. 2018. Performance of alum and assorted coagulants in turbidity removal of muddy water. Applied Water Science, 8, 40. Available at: https://doi.org/10.1007/s13201-018-0662-5.

Meyers, P.S. 1998. Sources of TOC in Deionized Water [online]. Available at: http://www.pi-corp.net/whitepaper/SourcesofTOCinDIWater.pdf [Accessed: 12 April 2020].

Nishat Ashraf, S., Rajapakse, J., Dawes, L.A., \& Millar, G.J. 2018. Coagulants for removal of turbidity and dissolved species from coal seam gas associated water. Journal of Water Process Engineering, 26, pp.187-199. Available at: https://doi.org/10.1016/j.jwpe.2018.10.017

Ranković, B., Simić, S., \& Bogdanović, D. 2006. Phytoplankton as Indicator of Water Quality of Lakes Bubanj and Šumarice during Autumn. Kragujevac Journal of Science, 28, pp.107-114 [online]. Available at: https://www.pmf.kg.ac.rs/KJS/volumes/kjs28/kjs28rankovicsimic107.pdf [Accessed: 15 April 2020].

Ritchie, R.J. 2006. Consistent Sets of Spectrophotometric Chlorophyll Equations for Acetone, Methanol and Ethanol Solvents. Photosynthesis Research, 89(1), pp.27-41. Available at: https://doi.org/10.1007/s11120-0069065-9.

\section{УЛУЧШЕННЫЕ ПРОЦЕССЫ ХИМИЧЕСКОЙ ОБРАБОТКИ ВОДЫ ИЗ РЕКИ СУШИЦЫ ЗЛАТИБОРСКОГО ОКРУГА И ПРИМЕНЕНИЕ ПОЛУЧЕННОГО ИЛА}

Мирьяна Р. Цвийович ${ }^{\text {, }}$ корреспондент, Милорад Р. Мурич ${ }^{6}$, Владица В. Чудич

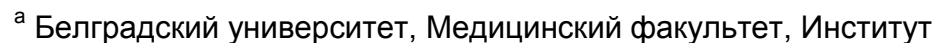

микробиологии и иммунологии, г. Белград, Республика Сербия

б Профильная академия Западной Сербии, г. Ужице, Республика Сербия

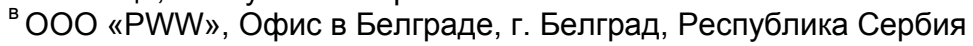

РУБРИКА ГРНТИ: 61.00.00 ХИМИЧЕСКАЯ ТЕХНОЛОГИЯ. ХИМИЧЕСКАЯ ПРОМЫШЛЕННОСТЬ;

61.13.21 Химические процессы

61.01.94 Охрана окружающей среды

ВИД СТАТЬИ: оригинальная научная статья

ЯЗЫК СТАТЬИ: английский 
Резюме:

Введение/цель: Концентрация природных органических и неорганических примесей, биологических видов и микроорганизмов в поверхностных водах истока реки Сушица изменчива. Эта вода заменила воду из озера Врутци, на которую сильно повлияла эвтроорикация. Данные воды нуждаются в очистке от загрязнения с помощью коагулянтов и полиэлектролитов. Целью исследования являлись: улучшение очистки поверхностных вод (коагуляция и фрлокуляция), уменьшение количества ила, оценка его качества, обработка и применение.

Методы: Разработаны фризико-химические методы определения параметров качества воды, ила и компоста. Исследуемые параметры: мутность, расход $\mathrm{KMnO}_{4}$, металлы, общий органический углерод, общий азот и хлорофилл.

Результаты: Качество поверхностных вод сильно влияет на содержание осадка. Концентрация металлов в иле составляет: 72200 мәке-1 Al, 8550 мәке-1 Fe, 106 мәке-1 Zn. Параметры металлов, превышающие предельно-допустимую концентрацию в воде: Ni 169 меке-1, Cr 69,5 мәке-1, Pb 5,7 меке-1 и должны быть снижены за счет иеолитов. Концентрации «питательных веществ»: 697 мгке-1 P, 297 мгке-1 К, 9,6 мәка-1 общего азота, 274 мг-кг растворенного органического углерода. Eserihia coli и Salamonella необходимы для преобразования ила в компост.

Выводы: После созревания компост можно использовать для выращивания Coriandrum salivum. В следующем исследовании данная стратегия будет применяться по отношению к воде и илу из озера Врутии.

Ключевые слова: поверхностные воды, проток воды, коагулация, фрлокулация, ил, компост.

УНАПРЕЪЕНИ ПРОЦЕСИ ХЕМИЈСКОГ ТРЕТМАНА ВОДЕ ИЗ РЕКЕ СУШИЦЕ У ЗЛАТИБОРСКОМ ОКРУГУ И ПРИМЕНА ЊЕНОГ МУЉА

Мирјана Р. Цвијовић ${ }^{a}$, аутор за преписку, Милорад Р. Мурић ${ }^{6}$, Владица В. Чудић

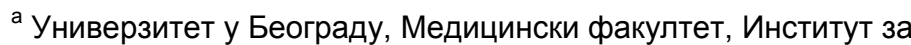

микробиологију и имунологију, Београд, Република Србија

${ }^{\sigma}$ Академија струковних студија Западне Србије,

Ужице, Република Србија

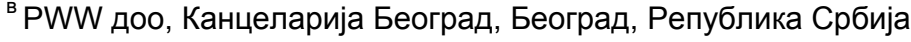

ОБЛАСТ: хемијске технологије

ВРСТА ЧЛАНКА: оригиналан научни рад

ЈЕЗИК ЧЛАНКА: енглески 


\section{Сажетак:}

Увод/циљ: У површинској води изворишта реке Сушице варира концентрација природних органских и неорганских нечистоћа, биолошких врста и микроорганизама. Ова вода заменила је воду из језера Врутци, на коју је снажно утицала еутрофрикација. Тим водама неопходно је уклањање загађивача коагулантима $u$ полиелектролитом. Циљ истраживања био је да се побољша третман површинске воде (коагулација и фолокулација), смањи количина муља, процени његов квалитет, третман и примена.

Методе: Физичко-хемијске методе развијене су за одређивање параметара квалитета воде, муља и компоста. Ти параметри су: замућеност, потрошња $\mathrm{KMnO}_{4}$, метали, укупни органски угљеник, укупни азот и хлорофил.

Резултати: Квалитет површинске воде увелико утиче на садржај муља. Концентрације метала у муљу су: 72200 мгке-1 Al, 8550 мгка$1 \mathrm{Fe}, 106$ мәке-1 Zn. Метали преко максималне границе су: Ni 169 меке-1, Cr 69,5 мәке-1, Pb 5,7 меке-1, и морају се редуковати зеолитима. Концентрације „храњивих састојака” су: 697 меке-1 $P$, 297 мгке-1 К, 9,6 мгке-1 укупног N, 274 мгке-1 раствореног органског угљеника. Eserihia coli u Salamonella битне су за претварање муља у компост.

Закључак: Након сазревања компост се може користити за гајење Coriandrum salivum. У наредном истраживању ова стратегија ће се применити на воду и муљ из језера Врутци.

Кључне речи: површинска вода, проток воде, коагулација, фолокулација, талог, компост.

Paper received on / Дата получения работы / Датум пријема чланка: 16.04.2020.

Manuscript corrections submitted on / Дата получения исправленной версии работы / Датум достављања исправки рукописа: 04.05.2020.

Paper accepted for publishing on / Дата окончательного согласования работы / Датум коначног прихватања чланка за објављивање: 06.05.2020.

(C) 2020 The Authors. Published by Vojnotehnički glasnik / Military Technical Courier (www.vtg.mod.gov.rs, втг.мо.упр.срб). This article is an open access article distributed under the terms and conditions of the Creative Commons Attribution license (http://creativecommons.org/licenses/by/3.0/rs/)

() 2020 Авторы. Опубликовано в «Военно-технический вестник / Vojnotehnički glasnik / Military Technical Courier» (www.vtg.mod.gov.rs, втг.мо.упр.срб). Данная статья в открытом доступе и распространяется в соответствии с лицензией «Creative Commons» (http://creativecommons.org/licenses/by/3.0/rs/).

(c) 2020 Аутори. Објавио Војнотехнички гласник / Vojnotehnički glasnik / Military Technical Courier (www.vtg.mod.gov.rs, втг.мо.упр.срб). Ово је чланак отвореног приступа и дистрибуира се у складу са Creative Commons licencom (http://creativecommons.org/licenses/by/3.0/rs/). 